\title{
RISIKO PENERAPAN PROFIT EQUALIZATION RESERVE (PER) PERBANKAN SYARIAH
}

\section{APPLICATION RISK PROFIT EQUALIZATION RESERVE (PER) ISLAMIC BANKING}

\author{
Maulana Hasanudin'1a, Afiaty Kurniasih ${ }^{2 b}$ \\ 1aJurusan Ekonomi Islam Fakultas Perbankan Syariah Universitas Djuanda, Jl. Tol Ciawi No. \\ 1, Kotak Pos 35 Bogor 16720 \\ 2bJurusan Perbankan Syariah Fakultas Ekonomi Islam Universitas Djuanda, Jl. Tol Ciawi No. \\ 1, Kotak Pos 35 Bogor 16720 \\ E-mail : 1amaulana.hasanudin@unida.ac.id, 2bafiaty.kurniasih@unida.ac.id
}

(Diterima oleh Dewan Redaksi: 16-01-2016)

(Dipublikasikan oleh Dewan Redaksi: 01-06-2016)

\begin{abstract}
This study aims to determine the possible risks against the possibility of applying Profit Equalization Reserve (PER) Islamic banking. The method used in the study is a model of Miles and Huberman, by way of data reduction, a data display and conclusion drawing/verification. Islamic banks in carrying out its business activities as an intermediary institution through mudharabah, must consider appropriate strategies to mitigate the risk.

At mudharabah, gains are not permanent or fluctuating, which raised the discourse to implement Profit Equalization Reserve (PER). The results showed that the Profit Equalization Reserve (PER) can be applied if an existing Islamic banking regulation in the form of DSN MUI fatwa on Profit Equalization Reserve (PER) and on the policy of the central office. In general, risks that may occur in the application of Profit Equalization Reserve (PER), namely Islamic banking financing risk, market risk, operational risk, liquidity risk, reputation risk, legal risk, strategic risk and compliance risk
\end{abstract}

Keywords: Profit Equalization Reserve (PER), Mudharabah Contract.

\section{ABSTRAK}

Penelitian ini bertujuan untuk mengetahui risiko yang mungkin terjadi terhadap kemungkinan penerapan Profit Equalization Reserve (PER) perbankan syariah. Metode yang digunakan dalam penelitian adalah model Miles and Huberman, yaitu dengan cara data reduction, data display dan conclusion drawing/verification. Hasil penelitian menunjukkan bahwa Profit Equalization Reserve (PER) dapat diterapkan pada perbankan syariah apabila sudah ada peraturan berupa fatwa DSN MUI mengenai ProfitEqualizationReserve (PER) dan atas kebijakan dari kantor pusat. Secara umum risiko yang mungkin terjadi pada penerapan Profit Equalization Reserve (PER) perbankan syariah yaitu risiko pembiayaan, risiko pasar, risiko operasional, risiko likuiditas, risiko reputasi, risiko hukum, risiko strategik dan risiko kepatuhan.

Hasanudin, Maulana. 2015. Risiko Yang Mungkin Terjadi Pada Penerapan Profit Equalization Reserve (PER) Perbankan Syariah. (3):167 - 180 


\section{PENDAHULUAN}

Saat ini, perbankan Indonesia telah menerapkan dual banking system yaitu sistem syariah dan konvensional. Perbankan yang menjalankan operasional berdasarkan syariah telah memberikan sistem perbankan yang saling menguntungkan bagi pihak bank dan masyarakat, serta mengedepankan aspek keadilan dalam transaksi, mengedepankan nilai-nilai kebersamaan dan persaudaraan dalam produksi, serta melakukan kegiatan usahanya dengan investasi atas prinsip bagi hasil dalam pembiayaan. Salah satu produk simpanan pada bank syariah adalah mudharabah

(bagi hasil),yaknikeuntungan yang diterima oleh nasabah tidak stabil (fluktuasi).Fluktuasi keuntungan yang diberikan oleh bank syariah terkadang lebih tinggi dari rate pasar maupun sebaliknya. Hal tersebut dapat mengakibatkan nasabah memilih untuk memindahkan dana ketika keuntungan yang diberikan oleh bank syariah lebih rendah dari rate pasar, sehingga perkembangan perbankan syariah akan mengalami penurunan dari segi penghimpunan dana maupun dari segi pembiayaan.

Fluktuasi dari keuntungan yang diberikan bank syariah kepada nasabah tersebut diakibatkan oleh siklus alamiah usaha (konjungtur) yakni kenyataan perekonomian yang terjadidi masyarakat berkembang secara tidak teratur sehingga mengalami kenaikan atau kemunduran yang selalu berubah-ubah dari waktu ke waktu. Fenomena tersebut tidak hanya berakibat terhadap keuntungan bank syariah, akan tetapi akan berakibat pula terhadap perkembangan perbankan syariah tersebut. Dalam menghadapi fenomena tersebut maka diperlukan pemikiran untuk mengatur pencadangan (reserve) yang harus disediakan oleh lembaga keuangan syariah khususnya perbankan syariah.

Produk deposito perbankan syariah bisa menggunakan akad mudharabah. Dalam akad ini shahibul maalakan transparansi terhadap risiko kerugian dana dan mudharib (bank syariah) akan berisiko kehilangan waktu dan usaha. Perbankan syariah akan menghadapi berbagai keterbatasan dalam pengelolaan dana yang disediakan oleh pemegang rekening investasi seperti deposito mudharabah, yakni keterbatasan instrument keuangan syariah. Risiko yang diambil oleh bank syariah bertujuan untuk mendapatkan return yang maksimal, bank syariah akan memberikan pengembalian yang menguntungkan bagi nasabah, sehingga nasabah tersebut akan memutuskan dimana dananya ditempatkan. Dalam memitigasi risiko akad mudharabah, bank syariah dapat menerapkan Profit Equalization Reserve (PER). Namun, penerapan Profit Equalization Reserve (PER) ini akan memungkinkan terjadinya risiko-risiko terhadap bank syariah tersebut. Hal ini merupakan ketentuan Allah SWT, seperti terdapat dalam Alqur'an surat Luqman ayat 34:

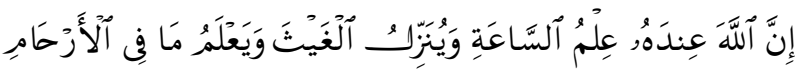

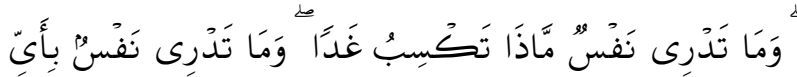

$$
\begin{aligned}
& \text { أَرْضِ تَمُوتُ إِنَّ الَلَّهَ عَلِيمُ خَبِيرُ }
\end{aligned}
$$

Artinya: ... dan tiada seorangpun yang dapat mengetahui (dengan pasti) apa yang akan diusahakannya besok ... (QS. Luqman: 34).

Ayat tersebut menjadi dasar pemikiran konsep risiko dalam Islam, khususnya kegiatan usaha dan investasi.Setiap usaha dan investasi yang akan dijalankan secara alami tidak akan selalu tetap mengalami keuntungan, sehingga akan adanya ketidakpastian. Konsep ketidakpastian menjadi salah satu pilar penting dalam proses manajemen risiko Islami. 
Berdasarkan uraian di atas, maka pertanyaanpenelitian ini adalah sebagai berikut:

1. Risiko-risiko apa saja yang mungkin terjadi pada penerapan Profit Equalization Reserve(PER) perbankan syariah?

2. Risiko apa yang dominan pada penerapan Profit Equalization Reserve(PER) perbankan syariah?

\section{MATERI DAN METODE}

\section{Jenis dan Objek Penelitian}

Jenis Penelitian dalam penelitian ini menggunakan deskriptif kualitatif.Yaitu penelitian yang dimaksudkan untuk menjelaskan setiap gejala yang terjadi secara holistic-kontekstual melalui pengumpulan data dari latar alami dengan memanfaatkan diri peneliti sebagai instrument kunci.Penelitian kualitatif bersifat deskriptif dan cenderung menggunakan analisis dengan pendekatan induktif.Penelitian kualitatif bermaksud untuk memahami fenomena tentang apa yang dialami oleh subjek penelitian secara holistik (utuh) dan dengan cara deskripsi dalam bentuk kata-kata dan bahasa pada suatu konteks khusus yang alamiah, serta dengan memanfaatkan berbagai metode alamiah yang salah satunya bermanfaat untuk keperluan meneliti dari segi prosesnya (Moleong, 2007:6).

Objek dari penelitian ini adalah instrumen Profit Equalization Reserve (PER) pada bank syariah.Penelitian ini terfokus pada risiko yang mungkin terjadi pada penerapan Profit Equalization Reserve (PER) BNI Syariah Cabang Sukabumi.

\section{Jenis dan Sumber Data}

Sumber data yang gunakan dalam penelitian ini terbagi menjadi 2 macam, yaitu :

\section{Sumber Data Primer}

Data Primer merupakan data dari hasil wawancara yang diperoleh dari
BNI Syariah Cabang

Sukabumi,dengan melakukan

wawancara terhadap beberapa

responden yakni Bapak Iwan

Setiawan supervisor pembiayaan dan

Ibu Embang selaku asisten supervisor pembiayaan dari BNI Syariah Cabang Sukabumi.

2. Data Sekunder

Adapun data sekunder pada penelitian ini diperoleh dari sumber kedua dari data yang dibutuhkan.Dalam penelitian ini, data sekunder tersebut berupa dokumen. Adapun metode pengumpulan datanya disebut metode dokumentasi, metode ini digunakan untuk mendapatkan data berupa data tertulis seperti buku, majalah, surat kabar, internet, serta laporan penelitian dokumen dan lain sebagainya.

\section{Teknik Pengumpulan Data}

Dalam usaha pengumpulan data yang diperlukan, maka metode pengumpulan data yang digunakan dalam penelitian ini adalah sebagai berikut :

1. Observasi

Observasi yang dilaksanakan dalam penelitian ini menggunakan observasi terbuka. Peneliti dalam melakukan pengumpulan data menyatakan sebenarnya kepada sumber data, bahwa sedang melakukan penelitian. Sehingga responden mengetahui sejak awal sampai akhir tentang aktivitas peneliti (Moleong, 2007:176). Dalam observasi, peneliti melakukan pengamatan secara langsung di tempat penelitian, sehingga dapat melihat sekaligus mencermati bagaimana pelaksanaan akad mudharabah, kemudian peneliti akan melihat hubungannya dengan penerapan ProfitEqualizationReserve (PER).

2. Teknik wawancara

Adapun yang peneliti wawancarai adalah supervisor dan asisten supervisor Divisi Pembiayaan Konsumer, guna mengetahui sejauh mana kemungkinan penerapan 
ProfitEqualizationReserve (PER) serta risiko yang mungkin terjadi ketika pihak bank syariah tersebut menerapkan Profit Equalization Reserve (PER). Dalam melakukan wawancara peneliti menggunakan metode wawancara semiterstruktur. Wawancara dengan menggunakan metode ini bertujuan untuk menemukan masalah yang lebih terbuka, informan diminta untuk memberikan pendapat tentang risiko yang mungkin akan terjadi pada penerapanProfit Equalization Reserve (PER) perbankan syariah.

3. Teknik dokumentasi

Dalam penelitian ini, dokumentasi diperoleh dari catatan-catatan dan rekaman yang diperoleh peneliti dari informan selama proses observasi dan wawancara berlangsung, serta dokumentasi ini diperoleh dari datadata perbankan syariah.

4. Teknik kepustakaan

Dalam mengambil data-data yang berkaitan dengan penelitian, peneliti menggunakan referensi yang bersumber dari buku, jurnal, majalah, artikel, surat kabar, internet dan sebagainya.

\section{Teknik Analisis Data}

Teknik analisis data yang dilakukan menggunakan model Miles and Huberman, yakni peneliti akan melakukan analisis data pada saat pengumpulan data berlangsung dan setelahnya dalam periode tertentu (Sugiyono, 2009: 246). Pada saat wawancara, peneliti telah melakukan analisis terhadap jawaban yang disampaikan oleh narasumber. Bila jawaban yang diberikan narasumber telah dianalisis dan masih belum memuaskan, maka peneliti akan melanjutkan pertanyaan lagi, sampai memperoleh data yang dianggap kredibel.Aktivitas dalam analisis data yakni sebagai berikut:

\section{Reduksi Data (Data Reduction)}

Reduksi data diartikan sebagai proses merangkum, memilih hal-hal yang pokok dari objek penelitian, memfokuskan pada hal-hal yang penting, kemudian dicari tema dan polanya. Dengan demikian data yang telah direduksi akan memberikan gambaran yang lebih jelas, dan mempermudah peneliti untuk melakukan pengumpulan data selanjutnya, dan mencarinya apabila diperlukan (Bahaddur, 2012:50).

2. Penyajian Data (Display Data)

Penyajian data adalah pendeskripsian sekumpulan informasi tersusun yang dapat memberikan kemungkinan penarikan kesimpulan dan pengambilan tindakan.Penyajian data kualitatif disajikan dalam bentuk teks naratif,matrik, diagram, tabel dan bagan (Sugiyono, 2009: 247).

3. Verifikasi dan Penegasan Kesimpulan (Conclution Drawing and Verification) Merupakan kegiatan akhir dari analisis data.Penarikan kesimpulan berupa kegiatan interpretasi, yaitu menemukan makna data yang telah disajikan (Bahaddur, 2012:50).

Selanjutnya data yang telah dianalisis, dijelaskan dan diberikan makna agar lebih mudah untuk mendiskripsikan fakta yang ada di lapangan dan menjawab pertanyaan penelitian yang kemudian diambil intisarinya saja.

Berdasarkan keterangan di atas, maka dalam setiap tahapan proses yang dilakukan untuk mendapatkan keabsahan data dengan melakukan analisis pada seluruh data yang telah diperoleh dari lapangan dan dokumen pribadi, dokumen resmi, gambar, foto dan sebagainya melalui metode wawancara yang didukung dengan studi dokumentasi sehingga menjadi lebih dapat dipercaya.

\section{HASIL DAN PEMBAHASAN}

Objek dalam penelitian adalah BNI Syariah CabangSukabumi. Penelitian ini 
dilaksanakan untuk mengetahui tentang risiko yang mungkin dapat terjadi dengan kemungkinan diterapkannya Profit Equalization Reserve (PER). Hasil wawancara yang dilakukan oleh peneliti merujuk kepada pertanyaan penelitian.

1. Kemungkinan penerapan

ProfitEqualizationReserve (PER)

Hasil penelitian yang dilakukan terhadap BNI Syariah mengenai kemungkinan diterapkannya ProfitEqualizationReserve (PER) pada perbankan syariah, yaitu BNI Syariah kemungkinan dapat menerapkan ProfitEqualizationReserve (PER) apabila sudah ada fatwa DSN MUI mengenai ProfitEqualizationReserve (PER) dan atas kebijakan dari kantor pusat. Dengan adanya instrument ProfitEqualizationReserve (PER) ini, maka BNI Syariah akan diharapkan dapat lebih kompetitif dengan bank syariah lainnya terutama dengan bank konvensional.

Profit Equalization Reserve (PER) atau cadangan dana dapat digunakan apabila return mudharabah mengalami penurunan, sehingga deposan tidak memindahkan dananya ke bank lain. Keuntungan yang diperoleh dari akad mudharabah oleh BNI Syariah untuk tiap bulannya tidaklah selalu sama, akan tetapi mengalami peningkatan dan penurunan tergantung dengan keberhasilan dari usaha yang dijalankan.

2. Risiko yang mungkin terjadi pada penerapan ProfitEqualizationReserve (PER) perbankan syariah

a. Risiko Pembiayaan

Dana mudharabah disalurkan oleh BNI Syariah Linkage sekitar 90\%, dana mudharabah tersebut disalurkan melalui pola pembiayaan berjenjang yakni dengan membiayai koperasi syariah, BPRS dan lembaga keuangan syariah lainnya. Dana yang disalurkan pun akan kembali kepada nasabah masing-masing lembaga keuangan syariah, sehingga return mudharabah BNI Syariah setiap bulannya selalu stabil.
Menurut analisis peneliti, meskipun return setiap bulannya selalu stabil, bank syariah seharusnya dapat menerapkan Profit Equalization Reserve (PER) karena dalam praktik dunia usaha keuntungan yang diperoleh tidaklah selalu sama, akan tetapi selalu bersifat konjungtur atau berfluktuasi sesuai dengan siklus alamiah usaha, serta kondisi perekonomian suatu Negara. Maka sudah semestinya bank syariah menerapkan ProfitEqualizationReserve (PER) untuk memitigasi risiko apabila return yang diterima mengalami penurunan sehingga mengakibatkan nasabah memindahkan dananya ke bank lainnya yang memberikan keuntungan yang lebih besar.

Usaha pada dasarnya merupakan sebuah aktivitas yang tidak bisa terlepas dari suatu ketidakpastian (uncertainty contracs). Dalam kerja sama bisnis atau investasi, para pelaku pasti akan menghadapi salah satu dari tiga kemungkinan yang ada, yaitu : untung, rugi, dan tidak untung dan tidak rugi. Jika penentuan keuntungan atau kerugian dari kegiatan bisnis atau investasi ini sudah ditetapkan sejak awal hanya ditanggung oleh salah satu pihak, maka kegiatan ini dapat dikategorikan sebagai aktivitas ribawi, karena telah memperlakukan kontrak yang berkarakter tidak pasti (uncertainty contracs) menjadi pasti (certainty contracs), sehingga aktivitas kontrak ini menjadi dilarang dalam Islam. Namun jika kedua belah pihak bersepakat sejak awal untuk memberlakukansharing riskterhadap kerugianmaupun keuntungan, maka kegiatan bisnis ini tetap sah dan diperbolehkan oleh Islam.

Sebelum dana mudharabah dialokasikan, maka BNI Syariah harus menganalisis risiko pada setiap jenis usaha yang akan dijalankan, seperti karakteristik dan kinerja keuangan pada usaha tersebut.

Dalam menilai risiko atas risiko pembiayaan, parameter yang 
digunakan adalah komposisi portofolioaset dan tingkat konsentrasi. Parameter tersebut berupa kualitas penyediaan dana dan kecukupanpencadangan, strategi penyediaan dana dan sumber timbulnya penyediaan dana, serta faktor eksternal. Tinggi rendahnya risiko pembiayaan dalam suatu aktivitas sangat dipengaruhi oleh beberapa faktor, antara lain kompleksitas produk atau aktivitas yang dilakukan bank, kerentanan (vulnerability) terhadap perubahan kondisi eksternal dan jenis atau karakteristik counterparty bank.

b. Risiko Pasar (Market Risk) Dalam risiko pasar, apabila nilai tukar rupiah terhadap mata uang asing mengalami penurunan yang diakibatkan oleh konsekuensi sehubungan dengan pergerakan atau fluktuasi nilai tukar terhadap laba rugi bank, sehingga dalam proses ProfitEqualizationReserve (PER)tidak sesuai denganekspektasi yang telah ditetapkan atau tidak dapat mencapai tujuan, sehingga apabila tidak sesuai ekspektasi maka ProfitEqualizationReserve (PER) ini tidak diterapkan.

Menurut analisis peneliti, risiko nilai tukar valuta asing (foreign exchange rate risk) timbul apabila bank syariah mengambil posisi terbuka. Di saat bank syariah berada pada posisi beli, kerugian akan terjadi bila nilai tukar mata uang lokal cenderung naik (menguat), dan sebaliknya pada saat bank syariah berada pada posisi jual, kerugian akan terjadi bila nilai tukar mata uang lokal cenderung turun (melemah). Risiko kurs ini akan meningkat apabila jumlah posisi yang diambil besar, baik posisi long maupun posisi short, dan fluktuasi pasar yang tinggi. Risiko nilai tukar valuta asing ini dapat ditekan dengan cara membatasi atau memperkecil posisi.

Bagi perbankan syariah, pada umumnya lebih mampu menghindari risiko nilai tukar valuta asing, karena perbankan syariah dituntut untuk mematuhi norma-norma syariah yang antara lain:

1) Bank syariah hanya melakukan transaksi komersil dan tidak akan pernah melakukan transaksi albitrage

2) Bank syariah hanya melakukan transaksi pertukaran valuta asing secara tunai

3) Bank syariah tidak melakukan short selling

4) Bank syariah tidak melakukan tanpa penyerahan (non delivery trading)

c. Risiko Operasional (Operational Risk)

Dalam praktiknya, penerapan

Profit Equalization Reserve (PER) diharapkan dapat menyeimbangkan return mudharabah deposan. Sehingga risiko operasional, yakni yang terjadi dari kelemahan pengawasan internal dan tata kelola perusahaan (corporategovernance) juga dapat menyebabkan jatuhnya pendapatan atau arus kas bersih bank dibandingkan dengan apa yang diharapkan atau ditargetkan, sehingga menimbulkan masalah likuiditas bank.

$\begin{array}{clr}\text { Bank } & \text { syariah } & \text { dalam } \\ \text { menjalankan } & \text { usahanya, } & \text { perlu }\end{array}$ memperoleh keuntungan. Dalam perolehan keuntungan, disyaratkan bahwa:

1) Keuntungan tidak boleh dihitung berdasarkan persentase dari jumlah modal yang dinvestasikan, melainkan hanya keuntungannya saja setelah dipotong besarnya modal. Dalam hal ini, perhitungan harus dilakukan secara cermat agar tidak membuat ketidakjelasan perhitungan yang akan membawa kepada suatu kontrak yang tidak sah.

2) Keuntungan untuk setiap pihak tidak ditentukan dalam setiap nominal, misalnya satu juta, dua juta, dan seterusnya. Jika ditentukan dengan nilai nominal, 
berarti shahibul maal telah mematok untuk nominal tertentu dari sebuah usaha yang belum jelas untung-ruginya, hal ini akan membawa pada perbuatan riba.

3) Nisbah pembagian ditentukan pada persentase misalnya 60:40\%, 50:50\%, dan seterusnya. Persentase-persentase tersebut tidak harus terikat pada bilangan tertentu.

d. Risiko Likuiditas (Liquidity Risk)

Risiko likuiditas biasanya terjadi karena kegagalan dalam mengelola dana atau karena kondisi ekonomi yang tidak kondusif yang menyebabkan likuiditas terganggu karena penarikan dana oleh nasabah secara terus-menerus, sehingga mengakibatkan bank tidak dapat memenuhi kewajiban jangka pendeknya. Instrument Profit Equalization Reserve (PER) itu sendiri termasuk kedalam kewajiban jangka pendek bank syariah.

Berdasarkan analisis peneliti, Profit Equalization Reserve (PER) merupakan kewajiban jangka pendek perbankan syariah yakni berada pada pos akuntansi kewajiban segera dibayar (KSD). Kewajiban segera adalah kewajiban bank kepada pihak lain yang sifatnya wajib segera dibayarkan (KSD) sesuai perintah pemberi amanat atau perjanjian yang ditetapkan sebelumnya. Adapun kewajiban segera terdiri dari:

a. Penerimaan pajak termasuk potongan pajak yang masih harus disetor. Kewajiban pajak untuk transaksi mata uang asing dibukukan dalam rupiah dengan menggunakan kurs yang ditetapkan oleh Menteri Keuangan pada saat pemotongan (pajak terutang).

b. Kewajiban yang sudah jatuh tempo namun belum ditarik seperti deposito mudharabah, setoran jaminan, bagi hasil yang belum diambil shahibul maal.

c. Dana transfer atau kiriman uang masuk dan keluar

d. Saldo rekening tabungan dan giro yang sudah ditutup namun belum diambil oleh pemilik rekening.

e. Komponen-komponen diatas apabila jumlahnya material dapat dikelompokan dalam pos tersendiri.

Keuntungan yang diperoleh dari akad mudharabah untuk tiap bulannya tidaklah sama, melainkan selalu berfluktuasi sesuai dengan siklus alamiah usaha. Dengan diberlakukannya Profit Equalization Reserve (PER), bank dapat mengelola penawaran dan permintaan likuiditas bank dengan tepat, sehingga dapat menjalankan usahanya dengan aman. Menjaga hubungan baik dengan pemangku kepentingan serta dapat menghindari masalah risiko likuiditas.

Dana yang diperbolehkan untuk memitigasi risiko pada usaha yang dijalankan bank syariah, adalah:

1) Dana Masyarakat (Dana Pihak Ketiga)

Dana pihak ketiga adalah dana yang diperoleh dari masyarakat, baikberasal dari individu, perusahaan, pemerintah, rumah tangga, Koperasi, Yayasan, dan lain-lain yangberbentuk mata uang rupiah maupun dalam valuta asing. Dana pihak ketiga terdiri dari:

a) Giro Wadi'ah (demand deposit), menggunakan prinsip wadi'ah yad dhamanah.

Giro wadiah adalah simpanan masyarakat baik dalam bentuk rupiah maupun valuta asing pada bank yang dalam transaksinya (penarikan dan penyetoran) dapat dilakukan 
setiap saat dengan menggunakan cek, bilyet giro, kartu ATM, sarana perintah bayar yang lainnya. Dalam produk ini menggunakan akad wadi'ah yad dhamanah. Wadiah yad dhamanah adalah akad wadi'ah yang membolehkan atau memberikan kesempatan kepada penerima titipan untuk menggunakan barang atau dana tersebut untuk tujuan tertentu yang menguntungkan dengan batasan pada saat pihak yang menitipkan barang atau dana membutuhkannya, maka pihak yang dititipi harus menyerahkan secara utuh.

b) Tabungan Wadi'ah (saving deposit), menggunakan prinsip wadi'ah yad dhamanah dan mudharabah mutlaqah

Tabungan adalah simpanan pihak ketiga dalam bentuk rupiah maupun valuta asing pada bank yang hanya dapat ditarik menurut syarat tertentu dari masing-masing bank penerbit.

Dalam produk ini menggunakan akad wadia'ah yad dhamanah dan mudharabah mutlaqah. Mudharabah mutlaqah. (investasi tidak terikat) adalah akad investasi dimana pihak shahibul maal tidak memberikan batasan dan syarat-syarat tertentu kepada mudharib dalam menginventasikan dananya

c) Simpanan Berjangka (Deposito iB)

Deposito berjangka adalah simpanan pihak ketiga dalam rupiah maupun valuta asing, yang diterbitkan atas nama nasabah kepada bank dan penarikannya hanya dapat dilakukan pada waktu tertentu menurut perjanjian antara penyimpan dengan bank yang bersangkutan.

2) Dana Pinjaman (Dana Pihak Kedua) Dana pihak kedua atau pinjaman merupakanpendanaan yang sumbernya berasal dari pihak yang memberikan pinjaman kepada bank. Dana pinjaman ini dapat diterima dari:

a) Pinjaman Bank Indonesia, merupakan pinjaman yang diperoleh karena bank tersebut mengalami kesulitan dalam memenuhi kewajiban jangka pendeknya dan atau pinjaman karena bank ditunjuk sebagai penyalur atau penerus pinjaman bantuan luar negeri.

b) Pinjaman dari bank lain di dalam negeri atau pinjaman antar bank (interbank call money). Pinjaman ini dilakukan untuk memenuhi kebutuhan menutup kewajiban kliring untuk memenuhi saldo Giro Wajib Minimum (GWM) di Bank Indonesia. Jangka waktu pinjaman relatif sangat singkat (overnight call money) dengan menggunakan instrumen sertifikat deposito, promes, dan Surat Berharga Pasar Uang (SBPU).

c) Repurchase Agreement, atau disebut dengan "Rips" atau "Ripos" adalah penjualan surat berharga sesuai dengan waktu yang diperjanjikan dengan harga yang ditetapkan dimuka.

d) Pinjaman dari bank (antarbank) dan atau lembaga keuangan di luar negeri, yaitu pinjaman yang lazimnya berbentuk pinjaman jangka menengah dan panjang, off shore loan dan pinjaman ini sebelumnya harus mendapat persetujuan dari Bank Indonesia karena berkaitan dengan kebijakan moneter.

e) Pinjaman dari Lembaga Keuangan Bukan Bank (LKBB), 
pinjaman ini lazimnya berupa surat berharga yang dapat diperjual belikan seperti sertifikat bank dan atau deposit on call dengan jangka waktu pendek dan dapat di perpanjang.

f) Obligasi (bonds) dan saham, bank-bank dapat memperoleh dana melalui pasar modal dengan cara emisi, baik dalam bentuk obligasi maupun saham.

3) Dana Sendiri (Dana Pihak Kesatu)

Dana sendiri atau dana pihak kesatu merupakan dana yang berasal dari pemegang saham atau pemilik. Pada dasarnya setiap bank akan selalu berusaha untuk meningkatkan jumlah dana sendiri, selain untuk memenuhi kewajiban dalam menyediakan modal minimum juga untuk memperkuat kemampuan ekspansi dan bersaing. Yang termasuk dana pihak kesatu:

a) Setoran modal dari pemegang saham.

b) Cadangan-cadangan bank, yaitu cadangan-cadangan laba tahun lalu yang tidak dibagi kepada para pemegang sahamnya.

c) Laba bank yang belum dibagi, merupakan laba yang memang belum dibagikan pada tahun yang bersangkutan sehingga dapat dimanfaatkan sebagai modal untuk sementara waktu.

Apabila bank sudah tidak dapat mengelola likuiditasnya, maka bank tersebut dapat mengakses ke pasar sekunder seperti ke pasar uang antar bank syariah (PUAS). PUAS dapat menjadi tempat bagi lembaga keuangan syariah untuk mengelola kebutuhan likuiditas jangka pendek.
Dalam memitigasi terjadinya risiko likuiditas, bank perlu melakukan perhitungan terhadap kesenjangan antara struktur dana dan struktur pinjaman berdasarkan periode jatuh tempo. Dalam upaya menjaga likuiditasnya agar selalu terjaga, perbankan juga memiliki Asset and Liability Committee (ALCO) yang senantiasa melakukan pemantauan terhadap kondisi makro ekonomi dan moneter serta melakukan evaluasi terhadap kondisi suatu bank yakni melihat manajemen likuiditas, gap, valuta asing, investasi dan pendapatan.

d. Risiko Hukum (Legal Risk)

Risiko Hukum yang akan dihadapi pada penerapan Profit Equalization Reserve (PER) adalah ketidakpatuhan para pihak terhadap aturan, fatwa dan kesepakatan, sehingga menimbulkan gugatan. Penerapan Profit Equalization Reserve (PER) dapat diterapkan apabila sudah ada aturan atau fatwa DSN MUI yang membolehkan pencadangan return mudharabah pada bank syariah, sehingga tidak melanggar peraturan atau hukum yang berlaku. Risiko hukum dapat terjadi karena kelemahan perikatan, gugatan hukum dan ketiadaan untuk mengukur dampak dari adanya perubahan peraturan.

Berdasarkan analisis peneliti, Profit Equalization Reserve (PER) dapat diterapkan oleh perbankan syariah karena sudah ada fatwa Dewan Syariah Nasional Nomor 87/DSNMUI/XII/2012 tentang metode perataan penghasilan (income smooting) dana pihak ketiga, yaitu "metode pemerataan penghasilan dengan membentuk dana cadangan adalah pengaturan distribusi keuntungan dari waktu ke waktu atas bagi hasil antara Lembaga Keuangan Syariah dan nasabah penyimpan dana dengan cara 
membentuk cadangan perataan atau penghasilan (Profit Equalization Reserve/PER)". Firman Allah SWT dalam QS. Al-Ma'idah ayat 1:

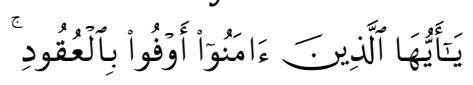

Artinya :"hai orang yang berimantunaikanlah akad-akad itu" (QS. Al-Ma'idah :1)

Sebagai makhluk sosial, manusia tidak lepas dari kegiatan interaksi dengan makhluk lain dalam rangka untuk memenuhi kebutuhannya. Hubungan antara satu manusia dengan manusia yang lainnya harus ada aturan yang menjelaskan hak dan kewajiban keduanya atas dasar kesempatan yang biasa disebut dengan akad, Islam sebagai agama yang komprehensif memberikan aturan yang jelas dan jalan akad untuk dapat diimplementasikan dalam kehidupan. Rasulullah SAW bersabda:

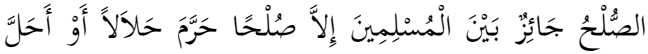

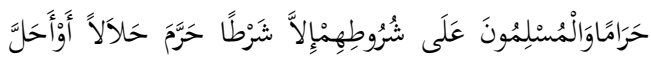

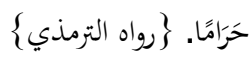

Artinya :Shulh (penyelesaian sengketa melalui musyawarah untuk mufakat). Boleh dilakukan oleh kaum muslimin kecuali shulh yang mengharamkan yang haram dan menghalalkan yang haram; dan kaum muslimin yang terikat dengan syarat-syarat mereka kecuali syarat yang mengharamkan yang halal atau menghalakan yang haram. (HR. Tirmidzi).

Makna dari diberlakukannya hukum atau fatwa DSN MUI mengenai perbankan syariah, yakni agar tidak terjadi kekeliruan atau pengalihan hak dengan cara yang bathil, sehingga dapat menjauhkan rahmat dan berkah dari Allah SWT dan tidak mengakibatkan reputasi bank menjadi buruk serta tidak terjadi gugatan dari nasabah.

Gugatan dari nasabah dapat terjadi karena pihak bank lalai atau alpa melaksanakan tugas sebagaimana yang telah disepakati oleh kedua belah pihak. Gugatan dari nasabah dapat mengakibatkan kerugian bagi bank, apabila gugatan tersebut dimenangkan oleh nasabah. Kerugian yang dialami oleh bank dapat berupa materi dan non materi yakni dapat mengganggu operasional serta likuiditas bank dan dapat mengakibatkan reputasi atau citra yang buruk bank tersebut dimata masyarakat.

e. Risiko Reputasi (Reputation Risk)

Menurut penuturan dari supervisor pembiayaan BNI Syariah bahwa Profit Equalization Reserve (PER) dapat diterapkan apabila sudah ada persetujuan dari deposan, sehingga tidak mengakibatkan citra yang buruk terhadap bank syariah tersebut.

Analisis yang dilakukan oleh peneliti berdasarkan pernyataan dari pihak responden mengenai risiko reputasi bank syariah dirasa sudah tepat.

Penilaian terhadap risiko reputasi atas diterapkannya Profit Equalization Reserve (PER) dapat dilihat dari beberapa indikator diantaranya:

1) Pengaruh reputasi dari pemilik bank dan perusahaan terkait, parameter pelanggaran etika bisnis, kompleksitas produk dan kerjasama bisnis, kualitas pemberitaan terhadap suatu bank, dan pengaduan nasabah. Reputasi dari pemilik bank dan perusahaan terkait dapat memberikan pengaruh terhadap reputasi suatu bank. Hal ini dapat diukur dari dua kriteria turunan yakni kriteria kredibilitas pemilik dan perusahaan terkait serta kriteria kejadian reputasi pada pemilik dan perusahaan terkait. Pengaruh pemilik dan perusahaan terkait umumnya sangat kuat terjadi pada bank swasta, atau dimiliki oleh perorangan ataupun asing. 
Perbankan yang dimiliki oleh Pemerintah Pusat (BUMN) dan Pemerintah Daerah (BUMD) jarang sekali reputasinya tercoreng apabila ada kejadian negatif yang menyebabkan reputasi pemilik menurun.

2) Pelanggaran etika bisnis yang dapat dilihat dari berbagai kriteria diantaranya transparansi informasi keuangan, kebijakan sumber daya bank, pemasaran produk dan jasa, penggunaan hak atas kekayaan intelektual, dan kerjasama bisnis dengan stakeholders lainnya.

3) Kompleksitas produk dan kerjasama bisnis yang terdiri dari berbagai kriteria yakni jumlah dan tingkat penggunaan nasabah atas produk bank yang kompleks serta jumlah dan materialitas kerjasama bank dengan mitra bisnis.

4) Frekuensi, materialitas dan eksposur pemberitaan negatif bank. Hal ini menjadi salah satu parameter yang paling krusial dalam melakukan pengendalian risiko reputasi. Pemberitaan di media massa harus dapat ditangani dengan cepat apabila terdapat pemberitaanpemberitaan negatif yang belum tentu benar namun sudah beredar luas di masyarakat dan diketahui oleh nasabah.

5) Pengaduan nasabah yang menunjukkan besar atau rendahnya serta materialitas pengaduan nasabah. Pengaduan nasabah hendaknya jangan selalu dipandang sebagai risiko, tetapi sebagai data base, sumber masukan yang berharga, sehingga pengaduan tersebut dapat diperbaiki dalam rangka meningkatkan pelayanan kepada nasabah atau masyarakat.
Dalam rangka menentukan kriteria transparansi informasi keuangan bank telah ditetapkan dalam peraturan Bank Indonesia. Peraturan tersebut terkait dengan transparansi kondisi keuangan dan non keuangan kepada pemangku kepentingan (stakeholders) dan disampaikan kepada pihak-pihak terkait. Peraturan tersebutBank Indoesia tersebut adalah Peraturan Bank Indonesia No. 7/50/ PBI/2005.Peraturan Bank Indonesia No. 3/22/PBI/2001 tentang Transparansi Kondisi Keuangan Bank, serta Surat Edaran Bank Indonesia No. 3/30/DPNP tanggal 14 Desember 2001. Surat Edaran Bank Indonesia No.7/10/DPNP tanggal 31 Maret 2005 perihal Laporan Keuangan Publikasi Triwulanan dan Bulanan Bank Umum serta Laporan tertentu yang disampaikan kepada Bank Indonesia.

Banyak hal yang bisa mendorong meningkatnya risiko reputasi.Namun ada beberapa cara untuk mengatasinya dengan mengurai parameter-parameter untuk mengukur risiko reputasi tersebut.Untuk parameter reputasi pemilik bank dan perusahaan terkait diharapkan agar selalu berkoordinasi dengan holding dalam membangun keselarasan berkomunikasi ataupun dalam upaya menjaga risiko reputasi. Begitu juga sebaliknya apabila suatu bank mendapatkan reputasi yang negatif yang sekiranya akan berpengaruh terhadap reputasi holdingnya, diharapkan agar segera berkoordinasi dengan holding group. Dalam upaya untuk mengantisipasi parameter frekuensi, materialitas dan eksposur pemberitaan negatif bank, bank perlu meningkatkan aktivitas media relationnya agar bisa memonitor apabila ada pemberitaan negatif. Perlu juga dianalis 
sebelumnya, faktor-faktor atau kejadian apa saja yang dapat menarik perhatian media atau memiliki newsvalue dan juga perlu diperhatikan faktor-faktor atau kejadian apa saja yang dapat menimbulkan pemberitaan negatif bagi bank. Dalam mengantisipasi pengaduan nasabah, hampir setiap bank memiliki CallCenter atau media komunikasi lain yang dapat dipergunakan untuk menampung pengaduan nasabah. Bahkan ada bank-bank yang mulai beralih ke media sosial untuk menampung pengaduan nasabah.Ada beberapa sudut pandang dalam melihat jumlah dan materialitas pengaduan nasabah. Jumlah pengaduan nasabah yang semakin meningkat tidak selalu dipandang sebagai menurunnya kualitas pelayanan, namun dicermati terlebih dahulu apabila bank tersebut mengalami pertumbuhan jumlah nasabah yang signifikan, bisa jadi hal itu yang menyebabkan bertambahnya jumlah pengaduan nasabah. Yang paling terpenting bukanlah jumlah pengaduan nasabahnya, namun seberapa besar tingkat penyelesaian terhadap pengaduan nasabah tersebut.

Secara umum risiko reputasi ini bukan merupakan risiko yang dikelola secara terpisah dari risikorisiko lainnya, khususnya bagi bank yang memiliki kompleksitas usaha yang tinggi, akan tetapi pengelolaan setiap aktivitas fungsional bank sedapat mungkin dapat terintegrasi ke dalam suatu sistem dan proses manajemen risiko yang akurat dan komprehensif.

f. Risiko Strategik (Strategic Risk)

Dengan penerapan Profit Equalization Reserve (PER) yakni dengan mencadangkan returnmudharabah untuk dialokasikan porsi mudharib apabila mengalami penurunan return dalam usaha sehingga return deposan dapat stabil. Akan tetapi dengan diterapkannya Profit Equalization Reserve(PER), maka akan mengubah aturan yang telah diterapkan oleh bank syariah.

Menurut analisis peneliti, pendapat tersebut kurang tepat karena bank syariah harus selalu siap dalam pengambilan keputusan dan bank syariah harus cepat dalam merespon perubahan-perubahan kondisi eksternal sehingga dapat bersaing dengan bank syariah yang lain khususnya dengan bank konvensional. Perubahan-perubahan kondisi eksternal suatu bank dapat berupa strategi bank dalam menjalankan tugasnya sebagai lembaga intermediary dan melaksanakan perubahan perundang-undangan dan ketentuan lain yang berlaku. Bank syariah dalam melakukan pembiayaan melalui akad mudharabah seharusnya dapat menerapkan ProfitEqualizationReserve (PER) sehingga strategi bank dalam menjalankan tugasnya dapat tercapai. Berbagai perubahan akan mempengaruhi perilaku para pemangku bank, seperti deposan yang apabila return mudharabah yang diterima mengalami penurunan, deposan tersebut dapat menjadi deposan pasif dan bahkan memindahkan dananya kepada lembaga keuangan lain yang memberikan keuntungan yang lebih besar.

Dengan penerapan Profit

Equalization Reserve (PER) diharapkan nasabah dapat loyal terhadap bank syariah, karena dengan keuntungan yang stabil maka nasabah akan merasa aman untuk menyimpan dananya pada perbankan syariah. Loyalitas nasabah akan menjadi kunci sukses, tidak hanya untuk jangka pendek, 
dapat bersaing yang berkelanjutan. Loyalitas nasabah dapat dijadikan sebuah acuan prestasi yang sesuai dengan visi misi bank syariah.

g. Risiko Kepatuhan (Compliance Risk) BNI syariah dapat menerapkan ProfitEqualizationReserve (PER) apabila sudah ada perundangundangan dan fatwa DSN MUI yang memperbolehkan diaplikasikannya ProfitEqualizationReserve

(PER)dalam usaha bank sebagai lembaga intermediary.

Berdasarkan analisis peneliti, bahwa peneliti setuju dengan pernyataan informan, karena dengan adanya peraturan yang memperbolehkan pencadangan return mudharabah maka bank syariah tersebut sudah menjalankan aktivitas usahanya sesuai dengan ketentuan syariat Islam melalui fatwa DSN MUI.

Risiko kepatuhan akan terjadi apabila bank tidak mematuhi atau tidak melaksanakan peraturan perundang-undangan dalam ketentuan lainnya yang berlaku, dalam hal ini adalah fatwa DSN MUI. Besarnya risiko kepatuhan diestimasi berdasarkan kemampuan bank untuk memenuhi seluruh peraturan pada waktu yang lampau atau yang akan datang.

Risiko kepatuhan diukur berdasarkan sejumlah parameter, yakni :

1) Jenis dari signifikansi pelanggaran yang dilakukan.

2) Frekuensi pelanggaran yang dilakukan.

3) Perilaku yang mendasari pelanggaran

4) Pelanggaran terhadap ketentuan atas transaksi keuangan.

\section{KESIMPULAN DAN IMPLIKASI}

Hasil penelitian ini menunjukkan beberapa kesimpulan dan implikasi sebagai berikut :
1. Profit Equalization Reserve (PER) pada perbankan syariah dapat diterapkan selama tidak bertentangan dengan Alquran dan hadits. Profit Equalization Reserve (PER) diterapkan untuk kemaslahatan umat, bank syariah diharuskan untuk memperoleh persetujuan dari pemilik rekening investasi terlebih dahulu untuk menerapkan Profit Equalization Reserve (PER), karena pemegang rekening investasi tidak mendapatkan return yang penuh untuk dicadangkan, ini berarti mengurangi hak nasabah dan perbuatan tersebut dilarang syariat Islam.

2. Risiko yang mungkin terjadi pada penerapan Profit Equalization Reserve (PER) Perbankan Syariah yaitu risiko pembiayaan, risiko pasar, risiko operasional, risiko likuiditas, risiko reputasi, risiko hukum, risiko strategik dan risiko kepatuhan.

3. Dalam penerapan Profit Equalization Reserve (PER), risiko yang timbul dominan adalah, risiko pembiayaan, risiko pasar, risiko operasional dan risiko likuiditas dan risiko hukum.

1. Diperlukan penelitian yang lebih mendalam mengenai risiko yang mungkin terjadi pada penerapan Profit Equalization Reserve (PER) perbankan syariah.

2. Diperlukannya sosialisasi kepada seluruh organisasi Bank Syariah untuk penerapan Profit Equalization Reserve (PER), karena dalam praktiknya pengetahuan mengenai Profit Equalization Reserve (PER) masih kurang.

3. Bank syariah diharapkan dapat menerapkan Profit Equalization Reserve (PER) karena telah terdapat fatwa mengenai penerapan Profit Equalization Reserve (PER) tersebut.

4. Bank syariah dapat memitigasi pemindahan dana oleh nasabah denganenerapan Profit Equalization Reserve(PER) sehingga tujuan bank syariah dapat tercapai sebagai lembaga intermediary. 


\section{DAFTAR PUSTAKA}

Antonio, Muhammad Syafi'i. 2001. Bank Syariah: Dari Teori ke Praktik. Jakarta: PT. Gema Insani Press.

Arifin, Zainul. 2006. Dasar-Dasar Manajemen Bank Syariah. Jakarta: Pustaka Alvabet

Archer, Rifaat dan Sundararajan. 2008. Apakah Profit Sharing Invesment Account (PSIA) Deposit atau Investasi? Implikasi Pengawasan dan Kecukupan Modala dari di Islamic Finance. Studi disiapkan untuk Islamic Financial Services Board (IFSB).

Badan Sertifikasi Manajemen Risiko. 2007. Indonesia Certificate In Banking Risk And Regulation. Jakarta.

Chapra, Umer. 2008. Regulasi \& Pengawasan Bank Syariah. Jakarta: Bumi Aksara.

Dendawijaya, Lukman. 2001. Manajemen Perbankan. Jakarta: Ghalian Indonesia.

Hakim, Cecep Maskanul. 2011. Belajar Mudah Ekonomi Islam. Banten: Shuhuf Media Insani.

Hassan, A. 2006. Tarjamah Bulugul-Maram Ibnu Hajar Al-'Asqalani. Bandung: CV Penerbit Diponegoro.

Kasmir. 2014. Dasar-dasar Perbankan. Jakarta: RajaGrafindo Persada.

Moleong, Lexy J. 2007. Metode Penelitian Kualitatif. Bandung: PT. Remaja Rosdakarya.

Mubarok, Jaih. 2013. Hukum Ekonomi Syariah Akad Mudharabah. Bandung: Fokusmedia.
Muhammad. 2002. Manajemen Bank Syariah. Yogyakarta:UUP AMP YKPN.

Muhammad. 2008. Manajemen Pembiayaan Mudharabah di Bank Syariah: Strategi Memaksimalkan Return dan Meminimalkan Risiko Pembiayaan di Bank Syariah sebagai Akibat Masalah Agency. Jakarta: PT. Rajawali.

Rivai, Veithzal dan Idroes. 2007. Bank and Financial Institution Management. Jakarta: Pt. Raja Grafindo Persada.

Rivai dan Veithzal. 2008. Islamic Financial Management. Jakarta: PT. Raja Grafindo Persada.

Roseeha, Dewi. 2010. Sukses Menulis Proposal, Skripsi, Tesis, dan Disertasi. Keen Books.

Saeed, Abdullah. 1996. Islamic Banking and Interest, A Study of Prohibition of Riba and Its Contemporary Interpretation. Leidan, New York, Koln: EJ. Brill.

Sugiyono. 2008. Metode Penelitian Kuantitatif \& Kualitatif. Bandung: Alfabeta.

Sundararajan. 2005. "Pengukuran Risiko, dan Pengungkapan Keuangan Islam dan Implikasi Bagi Hasil Account Investasi." Makalah yang dipresentasikan di Konferensi Internasional Keenam tentang Ekonomi Islam, Perbankan dan Keuangan, November 22-24, 2005. Jakarta-Indonesia. 